\title{
PENGGUNAAN METODE INKUIRI PADA PEMBELAJARAN MENULIS SURAT RESMI
}

\author{
Oleh \\ Dina Syahfitri \\ Dosen Universitas Graha Nusantara
}

\begin{abstract}
ABSTRAK
Penelitian ini bertujuan untuk mengetahui pengaruh metode pembelajaran inkuiri terhadap kemampuan siswa menulis surat resmi pada siswa kelas VIII SMP Negeri 1 Padangsidimpuan tahun pembelajaran 2013/2014. Populasi penelitian adalah seluruh siswa kelas VIII yang berjumlah 360 orang. Sampel diambil menggunakan teknik sampel random yaitu sebanyak 58 orang terdiri dari kelas VIII-1 dan VIII-2 masing-masing 29 orang. Penelitian ini menggunakan metode eksperimen dengan instrumen tes kemampuan menulis surat resmi. Tes ini diujikan sebanyak satu kali dengan menggunakan metode pembelajaran inkuiri. Karena penelitian ini bersifat koomparatif, maka harga skor variabel $\mathrm{X}_{\mathrm{A}}$ dan variabel $X_{B}$ diperbandingkan satu sama lain dengan menggunakan statistik " $t$ ". Berdasarkan hasil penelitian kemampuan menulis surat resmi dengan menggunakan metode pembelajaran inkuiri diperoleh nilai rata-rata 84,66 sedangkan pembelajaran konvensional diperoleh nilai rata-rata 67,76. Dari perolehan nilai rata-rata tersebut, maka hasil belajar menulis surat resmi dengan menggunakan metode inkuiri lebih baik daripada metode pembelajaran konvensional. Berdasarkan perhitungan dengan uji $\mathrm{t}$ diperoleh nilai $\mathrm{t}_{\mathrm{o}}=8,35$ kemudian dikonsultasikan dengan tabel t pada taraf signifikansi 5\% maupun $1 \%$ dengan $\mathrm{dk}=\left(\mathrm{N}_{1}-\mathrm{N}_{2}\right)$ ternyata $\mathrm{t}_{\mathrm{o}}$ yang diperoleh lebih besar dari $\mathrm{t}_{\mathrm{t}}$ yaitu 2,00< $8,35>2,66$ sehingga hipotesis nol ditolak dan hipotesis alternatif diterima. Hal ini berarti metode pembelajaran inkuiri lebih baik digunakan dalam pembelajaran menulis surat resmi dibandingkan dengan metode pembelajaran konvensional.
\end{abstract}

Kata Kunci : metode inkuiri, keterampilan menulis, surat resmi

\section{PENDAHULUAN}

Secara garis besar, keterampilan berbahasa dibedakan atas dua bentuk, yaitu keterampilan berbahasa reseptif dan keterampilan berbahasa produktif. Keterampilan reseptif diwujudkan dalam bentuk mendengar dan membaca. Sebaliknya, keterampilan produktif diwujudkan dalam bentuk berbicara dan menulis. Salah satu bentuk keterampilan produktif adalah menulis surat.

Keterampilan menulis surat resmi perlu dimiliki oleh setiap siswa. Hal itu tertuang dalam standar isi KTSP IMP Mata Pelajaran Bahasa Indonesia. Menulis surat resmi merupakan suatu kegiatan berkomunikasi yang berhubungan dengan 
masalah kedinasan dan dilakukan secara tertulis sesuai dengan ketentuan. Setelah menulis surat resmi, siswa diharapkan terampil menulis surat resmi dan memahami kaidah/ketentuan penulisan dalam surat resmi yang ditinjau dari aspek nonkebahasaan dan kabahasaan. Kedua aspek tersebut dijadikan indikator dalam penilaian surat resmi siswa.

Berdasarkan uraian di atas, pembelajaran menulis surat resmi menduduki peranan penting dalam upaya meningkatkan keterampilan menulis. Untuk itu guru hendaknya memberikan perhatian yang lebih terhadap siswa dalam menulis surat resmi agar setelah terjun di masyarakat siswa tidak mengalami kesulitan atau keraguan tentang bentuk dan bahasa dalam menulis surat resmi.

Untuk mengatasi masalah di atas penulis memilih metode inkuiri pembelajaran menulis surat resmi. Metode Inkuiri adalah cara penyajian pelajaran dengan memberi kesempatan kepada peserta didik untuk menemukan informasi dengan atau tanpa bantuan guru. Dimana metode inkuiri memungkinkan para peserta didik menemukan sendiri informasi-informasi yang diperlukan untuk mencapai tujuan belajarnya dan metode inkuiri ini terbukti cukup efektif digunakan sebagai metode pembelajaran dibandingkan dengan metode pembelajaran konvensional yang sifatnya searah.

Kondisi demikian memotivasi peneliti untuk membuat penelitian dengan judul "Pengaruh Metode Inkuiri Terhadap Keterampilan Menulis Surat Resmi Siswa Kelas VIII SMP Negeri 1 Padangsidimpuan Tahun Pembelajaran 2013/2014".

Tujuan penelitian ini adalah untuk menemukan pengaruh antara penerapan metode Inkuiri terhadap keterampilan menulis surat resmi siswa kelas VIII SMP Negeri 1 Padangsidimpuan tahun pembelajran 2013/2014

Metode inkuiri adalah sebuah model pembelajaran yang mampu menciptakan peserta didik yang cerdas dan berwawasan. Dengan metode ini peserta didik dilatih untuk selalu berpikir kritis karena membiasakan peserta didik memecahkan suatu masalah sendiri. Model ini bertujuan untuk melatih kemampuan peserta didik dalam meneliti, menjelaskan fenomena, dan memecahkan masalah secara ilmiah. 
Menurut Trianto (2009:114) pembelajaran dengan metode inkuiri memiliki 5 komponen yang umum yaitu question, student engangement, cooperative interaction, performance evaluation, dan variety of resources.

Adapun langkah-langkah pembelajaran metode Inkuiri menurut Trianto, (2009: 172 adalah (1) Menyajikan pertanyaan atau masalah, (2) Membuat hipotesis, (3) Merancang percobaan, (4) Melakukan percobaan untuk memperoleh hipotesis, (5) Mengumpulkan dan menganalisis data, (6) Membuat kesimpulan

Menurut Ruseffendi (2005:17) bahwa: "dalam metode konvensional, guru merupakan atau dianggap sebagai gudang ilmu, guru bertindak otoriter, guru mendominasi kelas". Dalam pembelajaran metode konvensional ditandai dengan ceramah yang diiringi dengan penjelasan, serta pembagian tugas dan latihan. Metode ceramah yang dianggap sebagai penyebab utama dari rendahnya minat belajar siswa terhadap pelajaran memang patut dibenarkan, tetapi juga anggapan itu sepenuhnya kurang tepat karena setiap metode atau model pembelajaran baik metode pembelajaran klasik termasuk metode ceramah maupun metode pembelajaran modern sama-sama mempunyai kelebihan dan kekurangan masingmasing yang saling melengkapi satu sama lain.

Surat resmi adalah surat yang digunakan untuk kepentingan resmi, baik perseorangan, instansi, maupun organisasi. Penggunaan surat resmi biasanya dipakai untuk undangan, surat edaran, dan surat pemberitahuan. Menurut Soedjito (1987:198)bahwa: "surat resmi ialah suatu alat sarana komunikasi tulis. Surat itu dipandang sebagai alat komunikasi tulis yang paling efisien, efektif, ekonomis dan praktis”. Sedangkan menurut Sabaruddin Ahmad (1980:23) mengemukakan bahwa: "surat resmi adalah surat yang diterbitkan oleh kantor-kantor/ jabatan pemerintah".

Kaidah penulisan unsur-unsur surat resmi oleh Kosasih, dkk. (2003 : 2142) yaitu (1)kepala surat yang ditujukan untuk memberikan informasi mengenai status dan alamat dari surat yang bersangkutan, (2) tanggal surat memudahkan pengarsipan surat, (3) nomor surat yang dibutuhkan pada surat, (4) lampiran banyaknya segala sesuatu yang diikut sertakan dengan surat, (5) hal atau perihal masalah pokok yang dibicarakan dalam surat, (6) alamat surat memuat keterangan mengenai nama dan tempat tinggal penerima surat. Selain itu 
hendaknya memuat, (7) salam pembuka, (8) tubuh surat semua berisi pikiran penulis yang hendak disampaikan kepada penerima surat, (9) penutup serta penanggung jawab surat, (10) tanda tangan nama yang dituliskan secara khas dengan tanda tangan (11) nama jabatan, dan (12) tembusan yang ditujukan untuk pihak lain.

Subyantoro (2004:50) aspek-aspek penulisan surat resmi yang perlu dinilai mencakup penulisan (1) unsur-unsur surat resmi, (2) ejaan dan tanda baca, (3) diksi, (4) bahasa surat.Senada dengan Subyanto, Akhadiah, dkk (2003:95) ada empat aspek pokok yang dijadikan kriteria penilaian, yaitu, (1) unsur-unsur surat resmi, (2) diksi (pilihan kata), (3) bahasa surat, (4) ejaan dan tanda baca.

Metode inkuiri merupakan metode pembelajaran yang berupaya menanamkan dasar-dasar berfikir ilmiah pada diri siswa, sehingga dalam proses pembelajaran ini siswa lebih banyak belajar sendiri, mengembangkan kreativitas dalam memecahkan masalah. Siswa benar-benar ditempatkan sebagai subjek yang belajar. Peranan guru dalam pembelajaran dengan metode Inkuiri adalah sebagai pembimbing dan fasilitator.

Penilaian yang dilaksanakan selama proses dan sesudah pembelajaran dengan metode inkuiri adalah dengan melihat kemampuan siswa dalam menulis surat resmi yaitu pada saat melakukan pemilihan kata (diksi). Siswa diminta untuk membuat sebuah surat resmi dengan menggunakan pemilihan kata yang baik dan benar sesuai dengan Ejaan Yang Disempurnakan (EYD).

Adapun hipotesis dari penelitian ini adalah : "Ada pengaruh yang positif dan signifikan metode inkuiri terhadap keterampilan menulis surat resmi kelas siswa VIII SMP Negeri 1 Padangsidimpuan tahun pembelajaran 2013/2014”.

\section{METODOLOGI PENELITIAN}

Penelitian ini dilaksanakan di SMP Negeri 1 Padangsidimpuan pada Tahun Ajaran 2012/2013 yang beralamat di Jln. Mesjid Raya Baru 3 Padangsidimpuan Utara.

Adapun yang menjadi populasi dalam penelitian adalah seluruh siswa kelas VIII SMP Negeri 1 Padangsidimpuan tahun pembelajaran 2012/2013 yang terdiri dari 12 kelas sebanyak 360 siswa. Sampel dalam penelitian ini diambil dua 
kelas (VIII 1 dan VIII 2) karena yang ingin diteliti adalah dua model pembelajaran. Satu kelas diajar dengan metode konvensioanal (VIII 2) dan satu kelas (VIII 1) lainnya dengan metode inkuiri. Kedua sampel ini dibimbing oleh guru yang sama (guru mata pelajaran bahasa indonesia).

Untuk mengetahui keterampilan menulis siswa yang diperoleh dengan penerapan dua perlakuan yang berbeda, maka kedua kelas diberikan tes. Sesudah perlakuan kedua kelas diberikan post test.

Untuk memperoleh data tentang keterampilan menulis maka instrumen yang digunakan adalah menulis surat resmi. Tes ini digunakan untuk mengetahui keterampilan siswa dalam menulis surat resmi. Untuk mengetahui kemampuan siswa dalam menulis surat resmi, diperlukan adanya penilaian.

Data yang diperlukan dalam penelitian ini adalah keterampilan menulis siswa sebelum dan sesudah perlakuan pengajaran dengan metode pembelajaran inkuiri dan dengan metode konvensional. Instrumen atau alat penelitian yang digunakan dalam penelitian ini untuk mengumpulkan data adalah tes hasil belajar. Tes tersebut dilakukan sesudah (post-test) diberi perlakuan pengajaran kepada siswa. Artinya diberikan pada awal dan akhir pengajaran di kelas. Tes ini dipakai untuk mengetahui kemampuan siswa sebelum dan sesudah menggunakan metode pembelajaran inkuiri.

Teknik analisis data dalam penelitian ini adalah menyusun data post-test dalam bentuk table, menghitung nilai rata-rata dan standar deviasi data sampel, uji normalitas, uji homogenitas, dan uji hipotesis.

\section{HASIL PENELITIAN DAN PEMBAHASAN}

Penelitian membagi dua kelompok, yaitu kelompok eksperimen yaitu kelompok yang sengaja dipengaruhi oleh variabel-variabel tertentu, dan kelompok kontrol, yaitu kelompok yang tidak dipengaruhi oleh variabel-variabel itu. Kelompok kontrol dimaksudkan sebagai pembanding.

Kelompok kontrol dalam penelitian ini adalah siswa yang mendapatkan pengajaran menulis surat resmi dengan metode pembelajaran konvensional, sedangkan kelompok eksperimen adalah kelompok siswa yang memperoleh pengajaran menulis surat resmi dengan dengan metode pembelajaran Inkuiri. 
Setelah data pada penelitian ini terkumpul, selanjutnya peneliti melakukan tabulasi data berdasarkan hasil belajar keterampilan menulis surat resmi siswa pada kelas eksperimen dan kelas kontrol, kemudian data dianalisis dengan mencari rata-rata dan standar deviasi, dan seterusnya dilakukan pengujian hipotesis penelitian. Berikut data penelitian yang didapat masing-masing kelompok.

Distribusi Frekuensi Nilai Keterampilan Menulis Surat Resmi Pada Kelompok Eksperimen $\left(\mathrm{X}_{1}\right)$

\begin{tabular}{|c|c|c|c|c|c|}
\hline $\mathbf{X}$ & $\mathbf{f}$ & $\mathbf{F x}$ & $\mathbf{X}$ & $\mathbf{x}^{\mathbf{2}}$ & $\mathbf{f x}^{\mathbf{2}}$ \\
\hline 68 & 1 & 68 & $-16,76$ & 280,898 & 280,898 \\
\hline 75 & 4 & 300 & $-9,76$ & 95,2576 & 381,03 \\
\hline 80 & 6 & 480 & $-4,76$ & 22,6576 & 135,946 \\
\hline 85 & 8 & 680 & 0,24 & 0,0576 & 0,4608 \\
\hline 90 & 5 & 450 & 5,24 & 27,4576 & 137,288 \\
\hline 95 & 4 & 380 & 10,24 & 104,858 & 419,43 \\
\hline 100 & 1 & 100 & 15,24 & 232,258 & 232,258 \\
\hline & 29 & $\sum f X=2458$ & & & $\sum f x^{2}=1587,31$ \\
\hline
\end{tabular}

Dari tabel di atas, selanjutnya dihitung nilai rata-rata atau mean, standar deviasi dan standar error.

1) Mean

$$
\begin{aligned}
M_{x} & =\frac{\sum f X}{N} \\
& =\frac{2458}{29} \\
& =84,76
\end{aligned}
$$

2) Standar Deviasi

$$
S D_{x}=\frac{\sqrt{\sum f x^{2}}}{N}
$$

Dari perhituzgan di atas diperoleh nilai rata-rata atau mean sebesar 84,76 , standar 7 deafatsi $\underline{\underline{3}}$ 7,40 dan standar error $=1,40$.

$$
=7,40
$$

\section{Distribusi Frekuensi Nilai Keterampilan MenulisSurat Resmi}

\section{Pada Kelompok Kontrol $\left(\mathbf{X}_{2}\right)$}




\begin{tabular}{|c|c|c|c|c|c|}
\hline $\mathbf{X}$ & $\mathbf{f}$ & $\mathbf{F x}$ & $\mathbf{X}$ & $\mathbf{x}^{\mathbf{2}}$ & $\mathbf{f x}^{\mathbf{2}}$ \\
\hline 68 & 5 & 340 & $-8,41$ & 70,7281 & 353,641 \\
\hline 70 & 2 & 140 & $-6,41$ & 41,0881 & 82,1762 \\
\hline 75 & 3 & 225 & $-1,41$ & 1,9881 & 5,9643 \\
\hline 76 & 7 & 532 & $-0,41$ & 0,1681 & 1,1767 \\
\hline 78 & 3 & 234 & 1,59 & 2,5281 & 7,5843 \\
\hline 80 & 4 & 320 & 3,59 & 12,8881 & 51,5524 \\
\hline 85 & 5 & 425 & 8,59 & 73,7881 & 368,941 \\
\hline & 29 & $\sum f X=2216$ & & & $\sum f x^{2}=871,035$ \\
\hline
\end{tabular}

Dari tabel di atas selanjutnya dihitung nilai rata-rata atau mean, standar deviasi dan standar error.

1) Mean

$$
\begin{aligned}
M_{x} & =\frac{\sum f X}{N} \\
& =\frac{2216}{29} \\
& =76,71
\end{aligned}
$$

2) Standar Deviasi

$$
\begin{aligned}
S D_{x} & =\frac{\sqrt{\sum f x^{2}}}{N} \\
& =\frac{\sqrt{871,035}}{29} \\
& =\sqrt{30,04} \\
& =5,48
\end{aligned}
$$

Dari perhitungan di atas diperoleh nilai rata-rata atau mean sebesar 76,41, standar deviasi $=5,48$ dan standar error $=1,04$

Uji Normalitas Data Kelompok Eksperimen $\left(\mathbf{X}_{1}\right)$

\begin{tabular}{|c|c|c|c|c|c|c|}
\hline $\mathbf{X}$ & $\mathbf{F}$ & $\mathbf{F}_{\text {kum }}$ & $\mathbf{Z i}$ & $\mathbf{F}(\mathbf{Z i})$ & $\mathbf{S}(\mathbf{Z i})$ & $\mathbf{L}$ \\
\hline 68 & 1 & 1 & $-2,27$ & 0,0117 & 0,0345 & 0,0228 \\
\hline 75 & 4 & 5 & $-1,32$ & 0,0933 & 0,1724 & 0,0791 \\
\hline 80 & 6 & 11 & $-0,64$ & 0,2598 & 0,3793 & 0,1196 \\
\hline 85 & 8 & 19 & 0,03 & 0,5130 & 0,6552 & 0,1422 \\
\hline 90 & 5 & 24 & 0,71 & 0,7609 & 0,8276 & 0,0667 \\
\hline
\end{tabular}




\begin{tabular}{|c|c|c|c|c|c|c|}
\hline 95 & 4 & 28 & 1,39 & 0,9171 & 0,9655 & 0,0484 \\
\hline 100 & 1 & 29 & 2,06 & 0,9804 & 1,0000 & 0,0196 \\
\hline
\end{tabular}

Berdasarkan tabel di atas, harga yang paling besar di antara hargaharga mutlak selisih tersebut adalah $\mathrm{L}_{\mathrm{o}}=0,1645$ dengan $\mathrm{n}=29$ dan taraf nyata $\alpha=0,05$ didapat $\mathrm{L}_{\text {tabel }}=0,1645$ yang lebih besar dari $\mathrm{L}_{\mathrm{o}}=0,1354$ sehingga hipotesis nol diterima. Dapat disimpulkan bahwa populasi berdistribusi normal.

Uji Normalitas Data Kelompok Kontrol $\left(\mathbf{X}_{2}\right)$

\begin{tabular}{|c|c|c|c|c|c|c|}
\hline $\mathbf{X}$ & $\mathbf{F}$ & $\mathbf{F}_{\text {kum }}$ & $\mathbf{Z i}$ & $\mathbf{F}(\mathbf{Z i})$ & $\mathbf{S}(\mathbf{Z i})$ & $\mathbf{L}$ \\
\hline 68 & 5 & 5 & $-1,53$ & 0,0624 & 0,1724 & 0,1100 \\
\hline 70 & 2 & 7 & $-1,17$ & 0,1211 & 0,2414 & 0,1203 \\
\hline 75 & 3 & 10 & $-0,26$ & 0,3985 & 0,3448 & 0,0536 \\
\hline 76 & 7 & 17 & $-0,07$ & 0,4702 & 0,5862 & 0,1160 \\
\hline 78 & 3 & 20 & 0,29 & 0,6141 & 0,6897 & 0,0755 \\
\hline 80 & 4 & 24 & 0,66 & 0,7438 & 0,8276 & 0,0838 \\
\hline 85 & 5 & 29 & 1,57 & 0,9415 & 1,0000 & 0,0585 \\
\hline
\end{tabular}

Berdasarkan tabel di atas, harga yang paling besar di antara hargaharga mutlak selisih tersebut adalah $\mathrm{L}_{\mathrm{o}}=0,1203$ dengan $\mathrm{n}=29$ dan taraf nyata $\alpha=0,05$ di dapat $\mathrm{L}_{\text {tabel }}=0,1645$ yang lebih besar dari $\mathrm{L}_{\mathrm{o}}=0,1203$, sehingga hipotesis nol diterima. Dapat disimpulkan bahwa populasi berdistribusi normal.

\section{Hasil Uji Homogenitas}

\begin{tabular}{|l|l|c|c|c|l|}
\hline Kelas & Varians & $\mathrm{F}_{\text {hitung }}$ & $\mathrm{F}_{\text {tabel }}$ & $\alpha$ & Keterangan \\
\hline Eksperimen & 54,73 & 1,82 & 1,88 & 0,05 & Homogen \\
\hline Kontrol & 30,04 & & & & \\
\hline
\end{tabular}

Harga $\mathrm{F}_{\text {hitung }}$ dibandingkan $\mathrm{F}_{\text {tabel }}$ diperoleh $\mathrm{F}_{\text {hitung }}<\mathrm{F}_{\text {tabel }}$ atau 1,82< 1,88 , berarti bahwa sampel yang berasal dari kelompok dalam penelitian ini dinyatakan homogen. Artinya, data yang diperoleh dapat mewakili seluruh populasi.

Pengujian hipotesis dengan uji " $t$ ".

$$
\begin{aligned}
t_{o} & =\frac{M_{1}-M_{2}}{S E m x_{1}-m x_{2}} \\
& =\frac{84,76-76,41}{1,74} \\
& =\frac{8,34}{1,74} \\
& =4,80
\end{aligned}
$$


Setelah $\mathrm{t}_{\mathrm{o}}$ diperoleh, selanjutnya dikonsultasikan dengan tabel $\mathrm{t}$ pada taraf signifikansi $5 \%$ maupun $1 \%$ dan dengan $\mathrm{dk}=\left(\mathrm{N}_{1}+\mathrm{N}_{2}\right)-2$ didapat $\mathrm{t}_{\mathrm{o}}=6,18$ dengan dk $(29+29)-2=56$. Karena $t_{o}$ yang diperoleh lebih besar dari $t_{t}$ yaitu $2,00<4,80>2,66$ maka hipotesis nihil (Ho) ditolak dan hipotesis alternatif (Ha) diterima.

Berdasarkan analisis data ditemukan bahwa metode pembelajaran inkuiri lebih efektif dibandingkan dengan metode pembelajaran konvensional dalam pembelajaran keterampilan menulis surat resmi. Perbedaan atau perbandingan tersebut disebabkan bahwa inkuiri lebih membantu siswa menemukan sendiri apa yang ia ketahui, sementara metode pembelajaran konvensional terfokus dari apa yang telah diajarkan guru sehingga siswa tidak bergairah menjawab tes.

Setelah didapat hasil dari penelitian ini, selanjutnya dibahas mengenai mengapa metode pembelajaran inkuiri lebih efektif dibandingkan dengan metode pembelajaran konvensional. Berbeda dengan pembelajaran konvensional, dalam hal ini pengajaran disampaikan atau dilakukan sepenuhnya oleh guru secara lisan atau penuturan. Peran siswa adalah sebagai pendengar yang teliti dan pencatat pokok persoalan yang dikemukakan oleh guru kemudian bertanya. Dalam pelaksanaannya dapat dilakukan melalui ceramah dan tanya jawab. Dalam pendekatan ini hubungan guru dengan siswa adalah berbicara.

Metode pembelajaran inkuiri lebih berusaha membantu siswa untuk menemukan dan memaknai konsep-konsep yang sulit apabila siswa dapat mendiskusikan masalah-masalah itu dengan temannya, sedangkan pada metode pembelajaran konvensional siswa hanya sebagai penerima informasi dari guru dan guru lebih banyak memberikan penjelasan atau ceramah saja.

\section{PENUTUP}

Berdasarkan hasil analisis data dan uji statistik pada bab keempat, maka dapat disimpulkan bahwa keterampilan menulis surat resmi dengan menggunakan metode pembejaran inkuiri memperoleh nilai rata-rata 84,66 lebih baik dibandingkan dengan menggunakan metode konvensional dengan nilai rata-rata 
67,76. Berdasarkan penghitungan dengan uji " $t$ " diperoleh nilai $t_{\mathrm{o}}=8,35$ kemudian dikonsultasikan dengan tabel t pada taraf signifikansi 5\% maupun $1 \%$ dengan $d k=\left(N_{1}-N_{2}\right)$ ternyata $t_{o}$ yang diperoleh lebih besar dari $t_{t}$ yaitu 2,00< $8,35>2,66$ sehingga hipotesis nol ditolak dan hipotesis alternatif diterima. Hal ini berarti Metode Pembelajaran Inkuiri efektif digunakan dalam pembelajaran keterampilan menulis surat resmi siswa Kelas VIII SMP Negeri 1 Padangsidimpuan Tahun Pembelajaran 2013/2014. Metode pembelajaran inkuiri lebih efektif digunakan dalam meningkatkan keterampilan menulis surat resmi siswa Kelas VIII SMP Negeri 1 Padangsidimpuan Tahun Pembela 2013/2014 bila dibandingkan dengan metode pembelajaran konvensional.

\section{DAFTAR PUSTAKA}

Arikunto, Suharsimi. 2006. Prosedur Penelitian Suatu Pendekatan Praktik. Jakarta : Rineka Cipta

Barus, Sanggup. 2008. Korespondensi Indonesia. Medan : USU Press

Depdiknas. 2005. Kamus Besar Bahasa Indonesia Edisi Ketiga. Jakarta : Balai Pustaka

Djamarah, Syaiful Bahri. 2006. Strategi Belajar Mengajar. Jakarta : Rineka Cipta

Rosyada, Dede. 2004. Pradigma Pendidikan Demokrasi Sebuah Model Pelibatan Masyarakat Dalam Penyelenggaraan Pendidikan. Jakarta: Kencana

Ruseffendi, E. T. 2005. Dasar-dasar Matematika Modern dan Komputer untuk Guru Edisi 5. Bandung: Tarsito.

Tarigan, Henry Guntur. 1983. Menulis Sebagai Suatu Keterampilan Berbahasa. Bandung : Angkasa

Tarigan, H.G. 1986. Menulis Sebagai Suatu Keterampilan Berbahasa. Bandung: Angkasa

Sabarti, Akhadiah. 1992. Pembinaan Kemampuan Menulis Bahasa Indonesia. Jakarta: Erlangga

Sudarsa, Caca dkk. 1992. Surat-Menyurat dalam Bahasa Indonesia. Jakarta: Pusat Pembinaan dan Pengembangan Bahasa.

Sugiono. 2009. Metode Penelitian Pendidikan Pendekatan Kuantitatif, Kualitatif, dan $R \& D$. Bandung : Alfabeta 
Soedjito, dan Solchan TW. 2004. Surat-Menyurat resmi Bahasa Indonesia. Bandung: PT Remaja Rosdakarya.

Sudidono, Anas. 2009. Statistika Pendidikan. Jakarta : Rajawali Pers

Sudjana, Nana. 2005. Penilaian Hasil Proses Belajar Mengajar. Bandung : Remaja Rosdakarya

Sugiono. 2009. Metode Penelitian Pendidikan Pendekatan Kuantitatif, Kualitatif, dan $R \& D$. Bandung : Alfabeta 